\title{
Pengembangan media pembelajaran Interaktif geokolase berbasis information and communication technologies (ICT)
}

\author{
Mohamad Hariyono ${ }^{1}$, Darnoto ${ }^{2}$ \\ ${ }^{1}$ Universitas Islam Nahdlatul Ulama Jepara \\ hariyono@unisnu.ac.id
}

\begin{abstract}
Abstrak : Penelitian ini bertujuan untuk : 1) menunjukan tahapan pengembangan media pembelajaran interaktif Geokolase berbasis ICT pada mata pelajaran Matematika, 2) menunjukan keefektifan dan kepraktisan media pembelajaran interaktif Geokolase berbasis ICT yang dikembangkan. Penelitian mengacu model pengembangan Plomp : (1) Investigasi Awal, (2) desain, (3) realisasi, (4) tes, evaluasi, dan revisi. Uji coba media pembelajaran dilakukan di SDN 8 Tulakan Donorejo sebagai kelas uji coba. Data diambil dari lembar validasi untuk mengukur kualitas media, lembar pengamatan, angket, tes, dan diolah dengan uji ketuntasan, dan uji banding. Hasil penelitian menunjukkan : (1) skor hasil validasi media Geokolase berbasis ICT 4,16 dengan interval 1-5 menunjukkan kriteria valid, (2) media pembelajaran yang dikembangkan adalah praktis, hal ini terlihat pada respon postif siswa dan kemampuan guru menggunakan media pembelajaran. (3) keefektifan pelaksanaan pembelajaran rata-rata pemahaman konsep kelas eksperimen sebesar 76,00 lebih besar daripada rata-rata pemahaman konsep kelas kontrol 68,05.
\end{abstract}

Kata kunci : Media Pembelajaran Interaktif; Geokolase Berbasis ICT;Matematika SD)

\begin{abstract}
The purpose of this study is to: 1) How the stages of developing interactive Geocolase learning media based ICT in Mathematics subjects, 2) How effectiveness and practicality of interactive Geocolase learning media based ICT. The study refers to the Plomp development model: (1) Initial Investigation, (2) design, (3) realization, (4) test, evaluation, and revision. Trial of instructional media was done at SDN 8 Tulakan Donorejo as a trial class. Data is taken from validation sheet to measure media quality, observation sheet, questionnaire, test, and processed by completeness test, appellate test. The results showed: (1) score of validation result of ICTbased Geocolase 4.16 media with interval 1-5 indicate valid criterion, (2) instructional media developed is practical, it is seen in student's positive responsiveness and teacher ability using instructional media. (3) the effectiveness of the average learning of the experimental class concept understanding is 76.00 greater than the average understanding of the concept of control class 68,05 .
\end{abstract}

Keywords: Interactive Learning Media, Geokolase based ICT, UnderstandingMathematica 


\section{Pendahuluan}

Pembelajaran geometri di sekolah dasar dimulai dengan cara sederhana dari konkrit ke abstrak, dari segi intuitif ke analisis, dari eksplorasi ke penguasaan dalam jangka waktu yang cukup lama, serta dari tahap yang paling sederhana hingga yang tinggi. Salam (2017) mengungkapkan bahwa anak-anak dalam belajar geometri melalui beberapa tahap yaitu: pengenalan, analisis, pengurutan, deduksi dan akurasi. Gabungan dari waktu, materi pelajaran, dan metode pengajaran yang dipakai untuk tahap tertentu akan meningkatkan kemampuan berpikir siswa kepada tahap yang lebih tinggi. Pengajaran geometri dapat melatih berpikir secara nalar, oleh karena itu geometri timbul dan berkembang karena proses berpikir.

Pada anak usia Sekolah Dasar yakni di usia 7-11 tahun peserta didik memasuki tahap usia operasi konkret (Ibda, 2015). Pada usia ini anak akan dapat menyerap pengetahuan secara mudah dengan bantuan benda-benda konkret. Oleh karena itu, sangat diperlukan media dalam pembelajaran di Sekolah Dasar. Media pembelajaran bisa dikatakan sebagai alat yang bisa merangsang peserta didik untuk terjadinya proses belajar. Pada mulanya, media pembelajaran hanya berfungsi sebagai alat bantu bagi guru untuk mengajar dan media yang digunakan baru sebatas alat bantu visual.

Semakin berkembangnya ilmu pengetahuan dan teknologi (IPTEK), khususnya dalam bidang pendidikan, saat ini penggunaan alat bantu atau media pembelajaran menjadi semakin luas dan interaktif, seperti adanya komputer dan internet. Selain membangkitkan motivasi dan minat peserta didik, media pembelajaran juga dapat membantu peserta didik meningkatkan pemahaman dan dapat, menyajikan materi atau data dengan menarik dan terpercaya, memudahkan penafsiran data, dan memadatkan informasi. Hariyono (2018) menyatakan pemaanfaatan multimedia komputer dapat meingkatkan pemahaman dan keyakinan matematika peserta didik serta kemampuaan pemecahan masalah.

Pemanfaatan teknologi informasi dan komunikasi dalam pembelajaran menjadi kebutuhan yang penting dalam penyelenggaraan pendidikan abad 21 dan pada kurikulum 2013. Pelaksanaan ujian nasional berbasis komputer telah berhasil dilaksanakan di 556 sekolah (SMP/MTs, 42,SMA/MA, 135, SMK 379) di 141 kabupaten/kota dan 30 provinsi serta dua sekolah Indonesia di luar negeri ( Pakpahan, 2016). Hal ini menjadi gambaran bahwa Indonesia secara bertahap walaupun pelan tapi pasti telah berusaha menggunakan perkembangan ICT dalam dunia pendidikan.

Pemberdayaan teknologi dalam pembelajaran matematika dapat meningkatkan kualitas pembelajaran. Komputer secara potensial dapat menggeser paradigma kegiatan pembelajaran dari konsentrasi pada ketrampilan manipulative ke pengembangan konsep, hubungan, dan ketrampilan memecahkan masalah. Menurut penelitian Hembree dan Dessart dalam 
Suherman (2003) menyimpulkan bahwa komputer sangat bermanfaat dalam meningkatkan ketrampilan memecahkan masalah, terutama untuk peserta didik yang memiliki kemampuan rendah dan tinggi dan penggunaan komputer dapat membuat peserta didik senang belajar matematika. Strategi pembelajaran matematika harus ditekankan pada pengembangan konsep daripada pengembangan ketrampilan. Oleh karena itu, jika penggunaan teknologi dapat digunakan dengan tepat dan efisien maka peserta didik diharapkan dapat menjadi problem solver yang handal, dapat meningkatkan pemahaman, dan dapat memiliki kemampuan berpikir matematika yang kuat

SDN 8 Tulaan dalam pembelajaran matematika selama ini masih terpusat kepada guru cenderung menggunakan metode ceramah dan masih minim dalam penggunaan media, sehingga dalam kegiatan belajar mengajar peserta didik menjadi sering bosan dan kurang perhatian terhadap materi yang diajarkan oleh guru. Hal ini dapat mengakibatkan rendahnya pemahaman konsep matematika peserta didik. Jika hal ini berkelanjutan maka akan berpengaruh pada hasil belajar peserta didik. Miskonsepsi geometri siswa SD berkaitan dengan bangun geometri dapat diketahui dari persepsi visual mereka masih kurang dan penalarannya pun masih sangat lemah. (Husnaeni, 2006)

Sulitnya materi geometri bangun datar bagi peserta didik, diantaranya yang menyebankanya adalah dalam kegiatan pembelajaran guru menyampaikan materi kepada peserta didik dengan pendekaatan yang abstrak. Konsep-konsep yang abstrak seharusnya dapat disajikan secara lebih nyata dengan bantuan media pembelajaran yang memudahkan peserta didik dalam memahami materi dan peserta didik dapat seacara aktif dalam kegiatan belajarnya. Hal ini sejalan dengan Dale yang mengatakan bahwa semakin banyak indera yang digunakan peserta didik dalam pembelajaran mala akan semakin baik daya ingat peserta didik sebagaimana yang digambarkan dalam kerucut pengalaman belajar. (Stepen et al., 2011)

Untuk mempermudah peserta didik dalam memahami konsep materi bangun datar dan mempermudah guru dalam menyampaikan materi pembelajaran, salah satunya adalah menggunakan media pembelajaran. Tentunya media pembelajaran yang digunakan harus sesuai dengan materi yang diajarkan. Salah satu media pembelajaran yang akan digunakan pada penelitian ini adalah media pembelajaran geokolase. Geokolase merupakan gabungan dari kata geometri dan kolase yang disingkat dengan nama Geokolase. Geokolase merupakan teknik menempel danmenyesuaikanwarnapadasuatuobjekgeometri. Kolase pada pembelajaran dapat melatih siswa untuk menjadi lebih bertanggung jawab dalam menyelesaikan tugas, melatih motorik halus peserta didik, dapat berkreativitas, mengeksplor dan berekspresi (Karimatulumah, Nur Amalia, \& Teach 2018). 
Geokolase merupakan gabungan dari kata geo dan kolase adalah media pembelajaran matematika yang memuat materi geometri yang di sajikan dalam bentuk kolase. Kolase adalah sebuah teknik menempel berbagai macam unsur ke dalam satu frame sehingga menghasilkan karya seni yang baru ( Toharoh \& Khasanah, 2017). Dengan demikian, kolase adalah karya seni rupa yang dibuat dengan cara menempelkan bahan apa saja ke dalam satu komposisi yang serasi sehingga menjadi satu kesatuan karya. Dalam hal ini geokolase yang dimaksud adalah kolase yang terbentuk dari bangun-bangun geometri seperti bangun datar sebagai materi matematika di Sekolah Dasar.

Geokolase berbasis ICT merupakan media yang dibuat menggunakan aplikasi komputer. Dalam media tersebut bersifat interaktif selain itu juga terdapat latihan, kuis serta soal-soal yang dapat digunakan peserta didik secara langsung. Diharapkan geokolase ICT menjadi media pembelajaran interaktif yang menarik, mamacu minat dan motivasi peserta didik sehingga kemampuan pemahaman konsep matematika pada bidang geometri di Sekolah Dasar semakin baik dan meningkat.

Berdasarkan uraian di atas, tujuan penelitian ini adalah untuk 1) menganalisis tahapan pengembangan media pembelajaran interaktif Geokolase berbasis ICT pada mata pelajaran Matematika, 2) menganalisis keefektifan dan kepraktisan media pembelajaran interaktif Geokolase berbasis ICT yang dikembangkan.

\section{MetodePenelitian}

Pendekatan penelitian yang digunakan adalah penelitian dan pengembangan. Pengembangan media pembelajaran interaktif geokolase berbasis ICT mengacu pada model pengembangan pendidikan umum dari Plomp (Rochmad, 2012) yang dimodifikasi, yaitu tanpa menyertakan fase implementasi setelah fase tes, evaluasi, dan revisi selesai dilakukan. Kegiatan-kegiatan yang dilakukan dalam pengembangan media pembelajaran sebagai berikut :

Tabel 1. Langkah-langkah penelitian dan pengembangan

\begin{tabular}{lll}
\hline No & Tahapan & Kegiatan \\
1 & Tahap investigasi awal & (1) analisis materi, (2) analisis kurikulum \\
& tentang materi geometri pada pelajaran \\
& matematika di Sekolah Dasar, (3) analisis \\
& kompetensi dan tujuan pembelajaran yang \\
& akan dicapai, dan (4) analisis penggunaan \\
& media pembelajaran dan kondisi \\
& laboratorium komputer sekolah \\
\hline
\end{tabular}




\begin{tabular}{ll}
\hline Tahap perancangan & Merancang/mendesain awal media \\
(desain) & pembelajaran interaktif geokolase berbasis \\
& ICT. Dari tahapan pendefinisian \\
& dilanjutkan dengan menyusun Draft I \\
& produk yaitu media pembelajaran \\
& interaktif geokolase berbasis ICT yang \\
& akan dikembangkan. Draft ini kemudian \\
& direview atau divalidasi oleh ahli materi \\
& dan media.
\end{tabular}

3 Tahap Realisasi

(1) menyusun desain media geokolase, (konstruksi)

(2) membuat algoritma pemrograman media geokolase dengan komputer, (3) menyusun script media interaktif geokolase berbasis ICT, dan (4) menyusun instrumen pengumpulan data. Hasil kegiatan pada fase ini disebut Draf 1

4 Tahap tes, evaluasi, Kegiatan validasi dan ujicoba draf hasil dan revisi validasi. Jenis instrumen yang digunakan dalam kegiatan validasi adalah lembar validasi. Dalam kegiatan ini juga meminta pertimbangan dari ahli dan praktisi kelayakan perangkat (pada Draf 1) yang telah direalisasikan. Jika hasil analisis menunjukkan: (1) valid tanpa revisi, maka kegiatan selanjutnya adalah uji coba lapangan, (2) valid dengan sedikit revisi, maka kegiatan selanjutnya adalah merevisi terlebih dahulu, kemudian langsung uji coba lapangan dan (3) tidak valid, maka dilakukan revisi sehingga dibuat model draf baru. 
Kegiatan uji coba dilakukan untuk melihat respon peserta didik dan respon guru terhadap media pembelajaran dan instrumen penelitian yang telah di validasi. Respon peserta didik dapat dilihat menggunakan lembar angket sedangkan respon guru dapat dilihat melalui pengamatan. Berdasarkan hasil uji coba bila belum memenuhi aspek kepraktisan maka dilakukan revisi. Selanjutnya, uji coba yang dilakukan juga bertujuan untuk melihat sejauh mana keefektifan pembelajaran menggunakan media pembelajaran interaktif geokolase berbasis ICT dalam pelaksanaan pembelajaran di kelas. Berdasarkan hasil ujicoba dan analisis data hasil ujicoba dilakukan revisi. Ujicoba dan revisi ini dapat dilalukan berulang-ulang sampai diperoleh draf pembelajaran yang diinginkan berdasarkan aspek-aspek keefektifan. Adapun kegiatan yang dilakukan pada waktu ujicoba adalah: (1) melakukan ujicoba, (2) melakukan analisis terhadap data hasil ujicoba, dan (3) melakukan revisi berdasarkan hasil analisis data hasil ujicoba. Analisis data validasiahli dan praktisi menggunakan rata-rata untuk memperoleh kevalidan media pembelajaran interaktif geokolase berbasis ICT sebelum diimplementasikan. Analisis keefektifan menggunakan uji ketuntasan Uji beda rata-rata untuk membandingkan pemahaman konsep peserta didik yang diajarkan dengan media pembelajaran interaktif geokolase berbasis ICT dengan peserta didik yang diajarkan dengan pembelajaran konvensional.

\section{Temuan dan Pembahasan}

1. Tahap investigasi awal

Berdasarkan hasil dokumentasi kurikulum, survey dan wawancara dengan peserta didik dan guru di SDN 8 Tulakan, secara umum kemampuan matematika peserta didik masih perlu ditingkatkan, terlihat dai nilai ulangan matematika pada penilaian akhir semester belum memuaskan. Pada saat kegiatan pembelajaran matematika di kelas cenderung menggunakan metode ceramah dan menggunakan LKS untuk latihan dan penugasan, dalam menggunakan media pembejaran masih minim terlebih media berbasis teknologi informasi, hal ini dikarenakan belum tersedianya media pembelajaran yang sesuai dengan materi pelajaran. SDN 8 Tulakan untuk kelas V masih menggunakan kurikulum KTSP, berdasarkan kompetensi dasar matematika SD kelas $\mathrm{V}$ merupakan titik awal dalam mengembangkan media pembelajran geokolase berbasis ICT. Dalam hal ini, semua kegiatan pembelajaran yang dilakukan harus mengacu kepada kompetensi tersebut. Selanjutnya secara spesifik indikator yang akan dicapai pada materi geometri bangun datar sebagai berikut: 
Tabel 2. Kompetensi dasar dan indikator matematika kelas V

\begin{tabular}{|c|c|}
\hline Kompetensi Dasar & Indikator \\
\hline \multirow[t]{6}{*}{$\begin{array}{l}\text { Mengidentifikasi sifat- } \\
\text { sifat bangun datar }\end{array}$} & $\begin{array}{l}\text { 1. Mendefinisikan konsep bangun datar secara verbal } \\
\text { dan tulisan. }\end{array}$ \\
\hline & $\begin{array}{l}\text { 2. Mengidentifikasi konsep bangun datar dan } \\
\text { membuat contoh dan bukan contoh. }\end{array}$ \\
\hline & $\begin{array}{l}\text { 3. Mengubah suatu bentuk representasi ke bentuk } \\
\text { lainnya. }\end{array}$ \\
\hline & $\begin{array}{l}\text { 4. Mengidentifikasi sifat-sifat suatu konsep bangun } \\
\text { datar dan mengenal syarat yang menentukan suatu } \\
\text { konsep. }\end{array}$ \\
\hline & $\begin{array}{l}\text { 5. Mengidentifikasi sifat-sifat suatu konsep bangun } \\
\text { datar dan mengenal syarat yang menentukan suatu } \\
\text { konsep. }\end{array}$ \\
\hline & $\begin{array}{l}\text { 6. Membandingkan dan membedakan konsep bangun } \\
\text { datar. }\end{array}$ \\
\hline
\end{tabular}

2. Tahap perancangan (desain)

Tahap perancangan ini memuat tentang materi pokok bahasan geometri bangun datar yang dirancang di atas kertas, baik rancangan gambar maupun teks. Tahapan ini bertujuan untuk memperoleh gambaran tentang apa yang nantinya ditampilkan pada computer based dengan menggunakan program visual basic 6. Pada menu utama permainan media pembelajaran Geokolase terdapat jenis-jenis bangun datar yang harus dipilih sesuai nama bangun tersebut dan ditempel ke media yang sudah ditentukan. Media pembelajaran yang dibuat ini merupakan media ajar yang terstruktur, artinya peserta didik harus menyelesaikan dari level 1 untuk bisa melanjutkan ke level berikutnya dan di setap level akan semakin sulit dalam tantangan dan soal yang dikerjakan. Gambar di bawah adalah contoh daridesain paper based. 

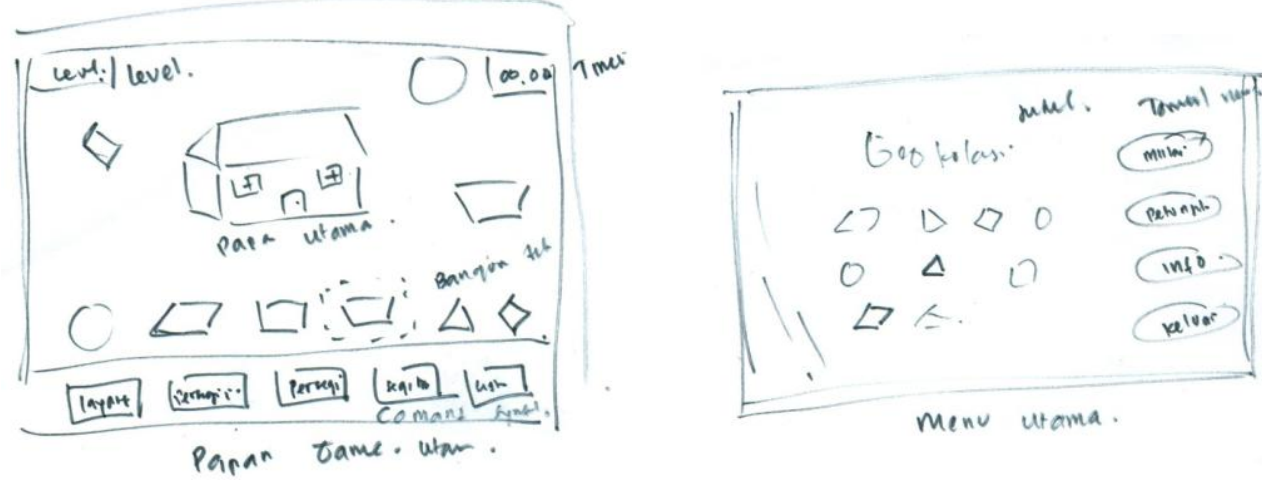

Gambar 1. Hasil Paper-Based

\section{Tahap Realisasi (konstruksi)}

Pada tahap realisasi ini desain produk yang telah dibuat dalam paper based dituangkan dalam bentuk computer based. Dalam pembuatan desain produk computer based ini menggunakan program visual basic 6 . Produk yang didesain dalam computer based ini merupakan Draf 1.
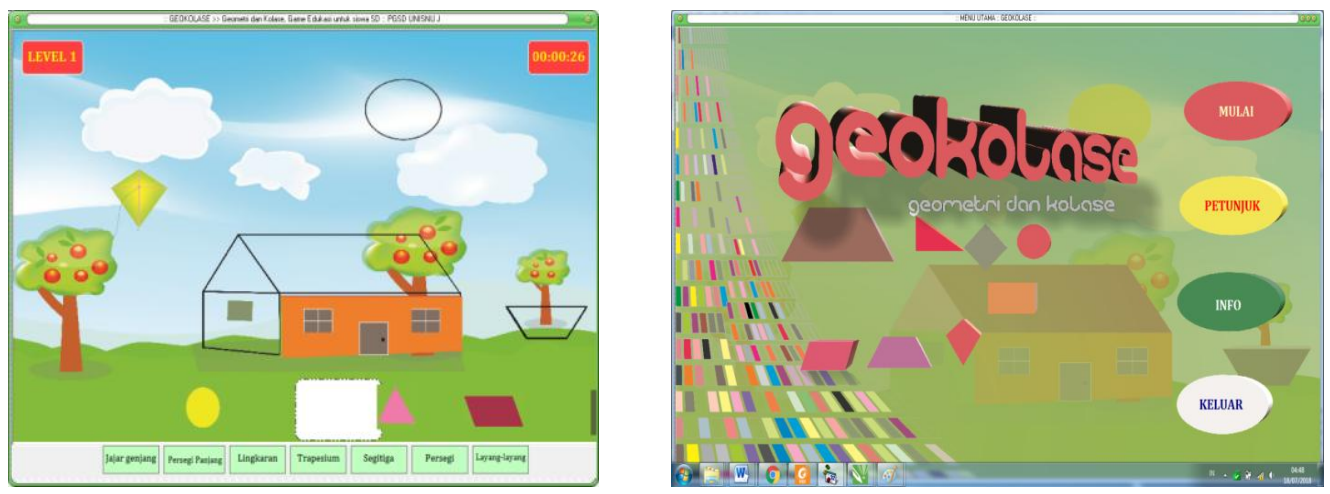

Gambar 2. Hasil Computer-Based

4. Tahap tes, evaluasi, danrevisi

Dalam penelitian ini media pembelajaran valid apabila hasil validasi perangkat yang dilakukan oleh validator (ahli dan praktisi) minimal baik media pembelajaran yang dikembangkan. Validator yang melakukan validasi dalam penelitian ini terdiri atas dua orang validator yangi terdiri dari ahli materi dan ahli media. Berdasarkan uji validasi ahli maka dapat disimpulkan desain produk media pembelajaran geokolase berbasis ICT (Draf 1) yang dikembangkan sudah tergolong baik, walaupun tentunya masih diperlukan perbaikan- 
perbaikan brdasarkan saran-saran validator. Saran-saran tersebut dijadikan acuan untuk pengembangan media pembelajaran selanjutnya.

Berdasar pada penilaian validator terhadap media pembelajaran geokolase berbasis ICT perlu dilakukan revisi. Beberapa saran-saran yang dilakukan untuk perbaikan adalah 1) variasi soal perlu ditambah dan menggunkan soal-soal yang lebih kontekstual; 2) petunjuk penggunaan apliakasi terlalu sederhana; dan 3) penambahan option timer untuk mengatur jalanya bangun-bangun geometri bangun datar. Hasil validasi tersebut berada pada memperoleh rata-rata 4,16 yang memiliki kriteria baik dan dapat digunakan dengan sedikit revisi.

Sebelum media pembelajaran diuji ke peserta didik di adakan pelatihan penggunaan media pembelajaran geokolase berbasis ICT kepada para pendidik dan sekaligus untuk melihatl kepraktisan media pembelajaran geokolase tersebut. Kepraktisan merupakan ukuran sejauhmana media pembelajaran geokolase mudah digunakan dalam pembelaajaran dan tidak membebani guru dalam pelaksanaan. Kepraktisan produk juga dimaknai sebagai upaya bagaimana melihat pendidik sebagai pengguna.

Dalam uji coba lapangan dilakukan perlu melihat kesulitan-kesulitan yang mungkin terjadi selama proses pembelajaran menggunakan media geokolase tersebut, sehingga dapat memberikan indikasi apakah media ajar tersebut perlu diperbaiki atau tidak. Pembelajaran dilakukan dengan menggunakan laptop dengan dibimbing guru atau peneliti. Pada saat pembelajaran dilakukan observasi terhadap peserta didik. Berdasarkan hasil observasi selama kegiatan pembelajaran peserta didik masih awal penggunaan mereka kesulitan mengoperasian media, namun setelah dibimbing oleh guru peserta didik dengan mudah dapat menggunakan aplikasi tersebut karena aplikasi user freandly.

Peserta didik juga diminta menjawab beberapa pertanyaan tentang media pembelajaran pokok geometri bangun datar. Jawaban peserta didik akan digunakan sebagai acuan untuk memperbaiki Draf 1. Berdasarkan jawaban, komentar, dan saran yang diberikan guru maupun peserta didik maka secara umum dapat dikatakan bahwa Draf 1 sudah baik dan tergolong media yang praktis.

Uji efektivitas ini dilakukan untuk mengetahui apakah media pembelajaran geokolase berbasis ICT efektif digunakan dalam pembelajaran matematika. Setelah dilakukan tes soal pemahaman konsep geometri bangun datar sebelum dan sesudah menggunakan media pembelajaran geokolase berbasis ICT pada proses pembelajaran diperoleh hasil sebagai berikut: 
Tabel 3.Nilai Rata-rata PretesdanPostes

Pemahaman Konsep Geometri Bangun Datar

\begin{tabular}{llllllllll}
\hline Pemahaman & Skor & \multicolumn{1}{l}{ Kelas Eksperimen $(\mathrm{N}=21)$} & \multicolumn{6}{c}{ Kelas Kontrol ( N=23) } \\
\cline { 7 - 11 } Konsep & Maks & $X_{\min }$ & $X_{\max }$ & $\bar{X}$ & $S$ & $X_{\min }$ & $X_{\max }$ & $\bar{X}$ & $S$ \\
Geometri & Tes & & & & & & & & \\
Bangun Datar & & & & & & & & & \\
\hline Pretest & 100 & 14 & 46 & 25,38 & 6,145 & 21 & 42 & 26,05 & 5,078 \\
\hline Postest & 100 & 56 & 94 & 76,00 & 9,326 & 46 & 89 & 68,05 & 8,678 \\
\hline
\end{tabular}

Setelah diperoleh data hasil pretes dan postes pada tabel 6 di atas kemudian dilakukan uji perbandingan rata-rata peningkatan pemahaman konsep. Namun sebelum itu, dilakukan uji normalitas dan uji homogenitas dan diperoleh bahwa skor pretes dan postes kemampuan pemecahan masalah matematika kelas eksperimen dan kontrol berdistribusi normal dan homogen. Oleh karena itu uji perbedaan rata-rata dua sampel yang digunakan adalah uji-t. Hasil perhitungan uji-t disajikan pada tabel 4 berikut ini :

Tabel 4. Hasil Uji Perbedaan Rata-rata Skor Postes

Pemahaman Konsep Geometri Bangun Datar

\begin{tabular}{ccccccc}
\hline Pretest & Kelas & $\bar{X}$ & $t$ & Df & Sig & Kesimpulan \\
Pemahaman & Eksperimen & 78,00 & 3,850 & 71 & 0,000 & Ada \\
\cline { 2 - 3 } Konsep & Kontrol & 68,25 & & & & Perbedaan \\
\hline
\end{tabular}

Berdasarkan tabel 4 di atas menunjukkan bahwa nilai t sebesar 3,770 dengan derajat kebebasan sebesar 71 dan nilai signifikan (p-value) sebesar 0,00. Karena nilai signifikan (pvalue) lebih kecil dari 0,05 maka hipotesis nol yang menyatakan bahwa tidak terdapat perbedaan rata-rata postes kemampuan pemahaman konsep peserta didik kelas eksperimen dan kontrol ditolak. Dengan kata lain, kemampuan pemecahan masalah peserta didik pada kedua kelompok setelah diberikan perlakuan adalah berbeda. Dalam hal ini berarti bahwa pemahaman konsep masalah peserta didik yang menggunakan media pembelajaran geokolase berbasis ICT lebih tinggi secara signifikan dibanding pemahaman konsep peserta didik yang mengunakan media biasa. Dengan demikian dapat dikatakan bahwa media pembelajaran geokolase berbasis ICT yang dikembangkan pada panelitian ini efektif dalam meningkatkan pemahaman konsep matematika materi geometri bangun datar. 


\section{Simpulan}

Media pembelajaran geokolase berbasis ICT yang dikembangkan adalah valid. Validnya media pembelajaran yang telah dikembangkan didukung oleh data hasil penelitian validasi dari validator ahli dan praktisi. Media pembelajaran yang dikembangkan adalah praktis, hal ini terlihat pada respon postif siswa dan kemampuan guru menggunakan media pembelajaran.Pembelajaran matematika dengan bantuan media pembelajaran geokolase berbasis ICT adalah efektif, Dalam hal ini pemahaman konsep masalah peserta didik yang menggunakan media pembelajaran geokolase berbasis ICT lebih tinggi secara signifikan dibanding pemahaman konsep peserta didik yang mengunakan media biasa.

\section{UcapanTerimaKasih}

Ucapan terimakasih kami sampaikan kepada DPRM yang Kementrian Riset dan Teknologi

Pendidikan Tinggi yang telah memberikan dana untuk melakukan penelitian ini.

\section{DaftarPustaka}

Hariyono, M. (2018).Pembelajaran Matematika Realistik Berbantuan Multimedia Client Server (MCS) Untuk Meningkatkan Kemampuan Pemecahan Masalah Dan Keyakinan Matematika. Jurnal Pendas, 2(1), 23-33.

Husnaeni.(2006). Penerapan Model Pembelajaran Van Hiele Dalam Membantu Siswa Kelas IV SD Membangun Konsep Segitiga. Universitas Terbuka: Jurnal Pendidikan, Volume 7, Nomor 2, September 2006, $67-78$.

Ibda, F. (2015).Perkembangan kognitif: teori jean piaget. Intelektualita, 3(1).

Karimatulumah, R., Nur Amalia, S. S., \& Teach, M. (2018). Kolase Sebagai Integrator Muatan Pelajaran Pada Pembelajaran Tematik Kelas IV Di SD Negeri Plosorejo 1 Kecamatan Gondang Kabupaten Sragen (Doctoral dissertation, Universitas Muhammadiyah Surakarta).

Pakpahan, R. (2016). Model Ujian Nasional Berbasis Komputer: Manfaat dan Tantangan. Jurnal Pendidikan dan Kebudayaan, 1(1), 19-35

Rahimah, N. (2017). Keterampilan Dasar Geometri Siswa Kelas V dalam Menyelesaikan Soal Bangun Datar Berdasarkan Kemampuan Matematika di Mi Al Istiqomah Banjarmasin. Math Didactic: Jurnal Pendidikan Matematika, 3(1), 55-63.

Rochmad, R. (2012). Desain Model Pengembangan Perangkat Pembelajaran Matematika. Kreano, Jurnal Matematika Kreatif-Inovatif, 3(1), 59-72

Salam, M. (2017). Pengaruh Model Pembelajaran Van Hiele Terhadap Kemampuan penalaran Geometris Siswa Kelas Ix Smp Negeri 2 Kendari. Jurnal Penelitian Pendidikan Matematika, 2(3), 107-118.

Stephen, M., W. Franklin, A. Elizabeth, K.Juma, \& O. Patrick. 2011. Teaching Computer Programming in the $21{ }^{\text {st }}$ Century. International Journal ofScience and Technology (IJST), $1(6): 247-252$ 
Toharoh, L., \& Khasanah, I. (2017). Pengaruh Kolase Daun Terhadap Keterampilan Motorik Halus Anak Pada Kelompok A Di TK Aba Aisyiyah 51 Semarang Barat 2016/2017. Paudia: Jurnal Penelitian Dalam Bidang Pendidikan Anak Usia Dini, 6(1). 